\title{
MINERAL RESOURCE POTENTIAL OF THE WEST NEEDLE WILDERNESS STUDY AREA, SAN JUAN AND LA PLATA COUNTIES, COLORADO
}

\author{
By \\ R. E. Van Loenen, U.S. Geological Survey \\ and \\ D. C. Scott, U.S. Bureau of ivines
}

\section{STUDIES RELATED TO WILDERNESS}

Under the provisions of the Wilderness Act (Public Law 88-577, September 3, 1964) and related acts, the U.S. Geological Survey and the U.S. Bureau of Mines have been conducting mineral surveys of Forest Service wilderness and primitive areas. Areas officially designated as "wilderness," "wild," or "canoe" when the act was passed were incorporated into the National Wilderness Preservation System, and some of them are presently being studied. The act provided that areas under consideration for wilderness designation should be studied for suitability for incorporation into the Wilderness System. The mineral surveys constitute one aspect of the suitability studies. The act directs that the results of such surveys are to be made available to the public and be submitted to the President and the Congress. In addition, the Federal Land Policy and Management Act, FLPMA (Public Law 94-579, October 21, 1976) requires the U.S. Geological Survey and the U.S. Bureau of Mines to conduct mineral surveys on certain Bureau of Land Management areas to determine their mineral resource potential. This report presents the results of a mineral survey of the West Needle Wilderness Study Area, San Juan National Forest, San Juan and La Plata Counties, Colorado, and the Bureau of Land Management's West Needles Contiguous Wilderness Study Area (CO-030-229A), San Juan County, Colorado. The West Needle Wilderness Study Area was established by Public Law 96-560, December 22, 1980. The West Needles Contiguous Wilderness Study Area (CO-030-229A) is being studied for wilderness suitability under section 603 of FLPMA.

\section{MINERAL RESOURCE POTENTIAL SUMMARY STATEMENT}

The West Needles Contiguous Wilderness Study Area (CO-030-229A) contains an area near the Elk Park mine that has a moderate mineral resource for uranium resources with associated silver, nickel, cobalt, copper, molybdenum, lead, and zinc. Recent exploration at Elk Park, an area adjacent to the wilderness study area boundary, has identified uranium resources, and the same structures and geologic conditions that localized the uranium mineralized bodies continue westward into the study area. No indications for other mineral or energy resources were identified by this study in the remainder of the West Needles Contiguous Wilderness Study Area or in the adjacent West Needle Wilderness Study Area. Although the study area is centered near important mining districts where mineralization is related directly to volcanic activity during Tertiary time, the study area does not contain Tertiary igneous rocks, and it probably was not affected by the nearby volcanic activity.

\section{INTRODUCTION}

\section{Location and topography}

The rugged West Needle Mountains lie within the San Juan National Forest, midway between Durango and Silverton and west of the Animas River, in southern Colorado. The study area occupies approximately $34 \mathrm{sq} \mathrm{mi}$, or nearly all of the West Needle Mountains. Of this total area about $25 \mathrm{sq} \mathrm{mi}$ lies within the West Needle Wilderness Study Area, La Plata and San Juan Counties, and is managed by the U.S. Forest Service. The remaining $9 \mathrm{sq} \mathrm{mi}(5,780$ acres) lies within the West iveedles Contiguous Wilderness Study Area (CO-030-229A) and is managed by the U.S. Bureau of Land Management. Both areas were studied simultaneously and are discussed in this report as a single area-the West Needle Wilderness Study Area (here referred to as the WSA or the study area).

As the name implies, the West Needle Mountains are made up of very steep and rugged picturesque peaks resulting largely from glaciation. Altitudes range from $7,800 \mathrm{ft}$ along the Animas River to more than $13,000 x_{t}$ on the Twilight Peaks. A spectacular natural boundary around most of the study area is provided by the Animas River Canyon on the east and south and Lime and Cascade Creeks on the west. The northern boundary, not as clearly defined topographically, is in part marked by Three Lakes Creek and Molas Creek. All drainage from the study area is into the Animas River, which runs south through Durango, Colo., and into the San Juan River. 


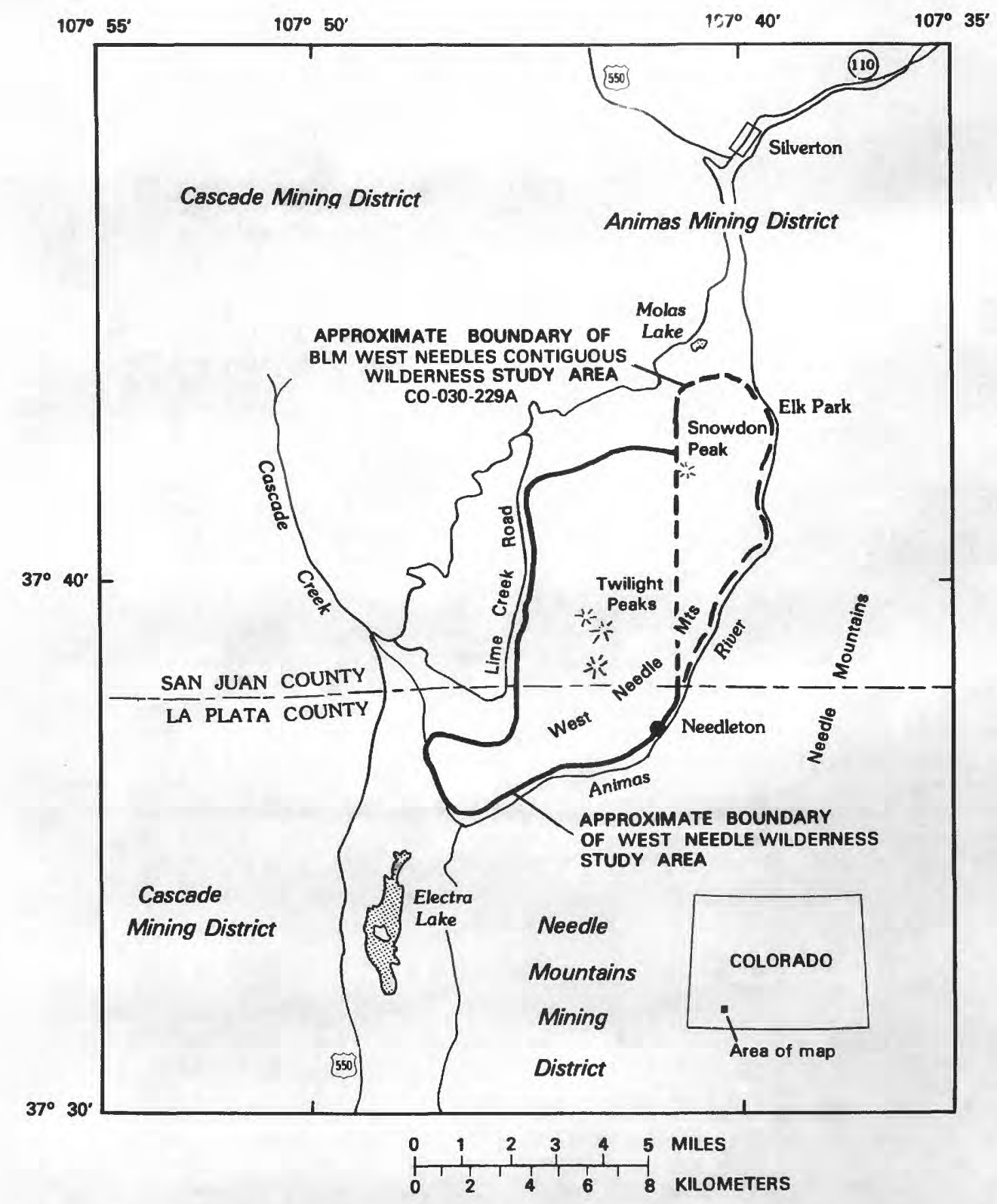

Figure 1.--Index map showing location of the West Needle Wilderness Study Area, San Juan and La Plata.Counties, Colorado. 
The area is accessible from U.S. Highway 550, the major road between Durango and Silverton, Colo.; the Lime Creek road, U.S. Forest Service road 591, which follows parts of the western boundary; and the Durango-Silverton Narrow Gauge Railroad, which follows the eastern boundary along the Animas River. The narrow-gauge railroad and railroad right-of-way, which separate the West Needle WSA from the Weminuche Wilderness, provides access to several trails leading into both areas. This railroad, completed in 1882 for shipping ore from Silverton to Durango, is now a very popular tourist attraction; it operates only during the summer months.

\section{Previous studies}

Early geologic investigations of the West Needle Mountains were conducted by Whitman Cross of the U.S. Geological Survey and his associates in the early 1900 's. These excellent studies were published in the Needle Mountain folio (Cross and others, 1905) and the Engineer Mountain folio (Cross and Hole, 1910). Barker $(1969 \mathrm{~b})$, in a restudy of the Precambrian rocks of the Needle Mountains, presents a detailed description of all rock units as well as several radiometric ages used in establishing a geologic history of the Precambrian rocks of the region. Specialized studies of fossil placer-type deposits in the Precambrian Uncompahgre Formation were done by Barker (1969a) for gold and by Burns and others (1980) for uranium.

\section{Present investigations}

Field studies by D. C. Scott of the U.S. Bureau of Mines included an examination of known mineralized areas and a search of County Courthouse, U.S. Bureau of Land Management, and U.S. Forest Service records for claims (Scott, 1983).

A geologic and geochemical survey of the study area was completed by R. E. Van Loenen with assistance from S. D. Birmingham of the U.S. Geological Survey during the summer of 1982 (Van Loenen, 1983).

\section{GEOLOGY}

The West Needle Mountains are the western part of the Needle Mountain uplift, a deeply eroded domal arch that consists of a large mass of metamorphic and igneous rocks of Early and Middle Proterozoic age (Proterozoic X and Y) (fig. 2). The uplift is flanked on the north and east by the Tertiary San Juan volcanic field and on the south and west by Paleozoic and younger sedimentary rocks. The metamorphic rocks, which comprise most of the study area, are of two distinct types: an older group derived from pre-1.7 b.y. old volcanic, intrusive, and sedimentary rocks termed the Twilight Gneiss, and a younger succession of clastic rocks, including quartzites and slates, called the Uncompahgre Formation, deposited sometime between 1.4 and 1.7 b.y. ago. Both units are intruded by granites and were highly deformed during several periods of metamorphism. The ages of the metamorphic rocks were established by the radiometric dating of the Eolus and Tenmile granite plutons (Barker, 1969b).
The Uncompahgre Formation unconformably overlies the Twilight Gneiss in a synclinorium extending east-west in an arc along the northern part of the Needle Mountain uplift. This formation is isoclinally folded along east-west trends in the northeastern part of the study area; subsequent faulting of the fold belt has provided conditions for mineralization near the WSA boundary at Elk Park.

The Twilight Gneiss is a very thick, strongly foliated sequence of felsic gneiss interlayered with varying amounts of mafic rock, both metamorphosed to amphibolite facies. Minor amounts of base and precious metals are present in fault structures in this gneissic turrane in the southern part of the WSA.

Paleozoic sedimentary rocks occur only in the northern part of the study area; major faults there have juxtaposed younger Paleozoic rocks against the older Uncompahgre Formation and Twilight Gneiss.

A geologic map and text by Van Loenen describing the geologic setting, structure, and rock units is published separately (1983).

\section{GEOCHEMISTRY}

A geochemical survey of the West Needle Wilderness Study Area did not identify any previously unknown areas of anomalous mineralization. Rock and stream-sediment samples were collected and analyzed to characterize the known mineral occurrences in and around the study area, establish background values for important element concentrations in altered and unaltered rocks, and to locate any anamolous areas.

Fifty-four rock samples, 6 panned concentrates, and 80 stream-sediment samples were collected and analyzed spectrographically for 31 elements. Selected samples were analyzed by other methods for the following additional elements: gold, uranium, thorium, and zinc. A complete list of the elements looked for, values assigned, analyst, methods, detection limits, and sample localities are given by Birmingham and Van Loenen (1983).

Overall, stream-sediment samples collected from drainages over the study area were generally low in metals. Some sediments were enriched in chromium, nickel, cobalt, and copper supplied by amphibolites and mafic igneous dikes, rock types that are common in the study area. A few stream-sediment samples from Lime Creek contain anomalous amounts of molybdenum, gold, silver, and zinc. These metals were probably derived from base- and precious metal-bearing veins within Paleozoic rocks to the north and northwest of the study area. Silver and molybdenum, which occur in trace amounts in slate units of the Uncompahgre Formation were also fed into Lime Creek. Silver $(0.5 \mathrm{ppm})$ and molybdenum (50 ppm) are not considered anomalous in slates (black shales) at these concentration levels. The metal content of the slates is relatively low; vanadium, which can indicate the presence of important metals in black shales, is quite low at $300 \mathrm{ppm}$.

A trace amount (10-30 ppm) of tin was found in stream-sediment samples collected from Twilight Creek. A probable source for this anomaly is a muscovite-rich quartzo-feldspathic rock in the Twilight Gneiss. These values do not indicate a mineral resource. 

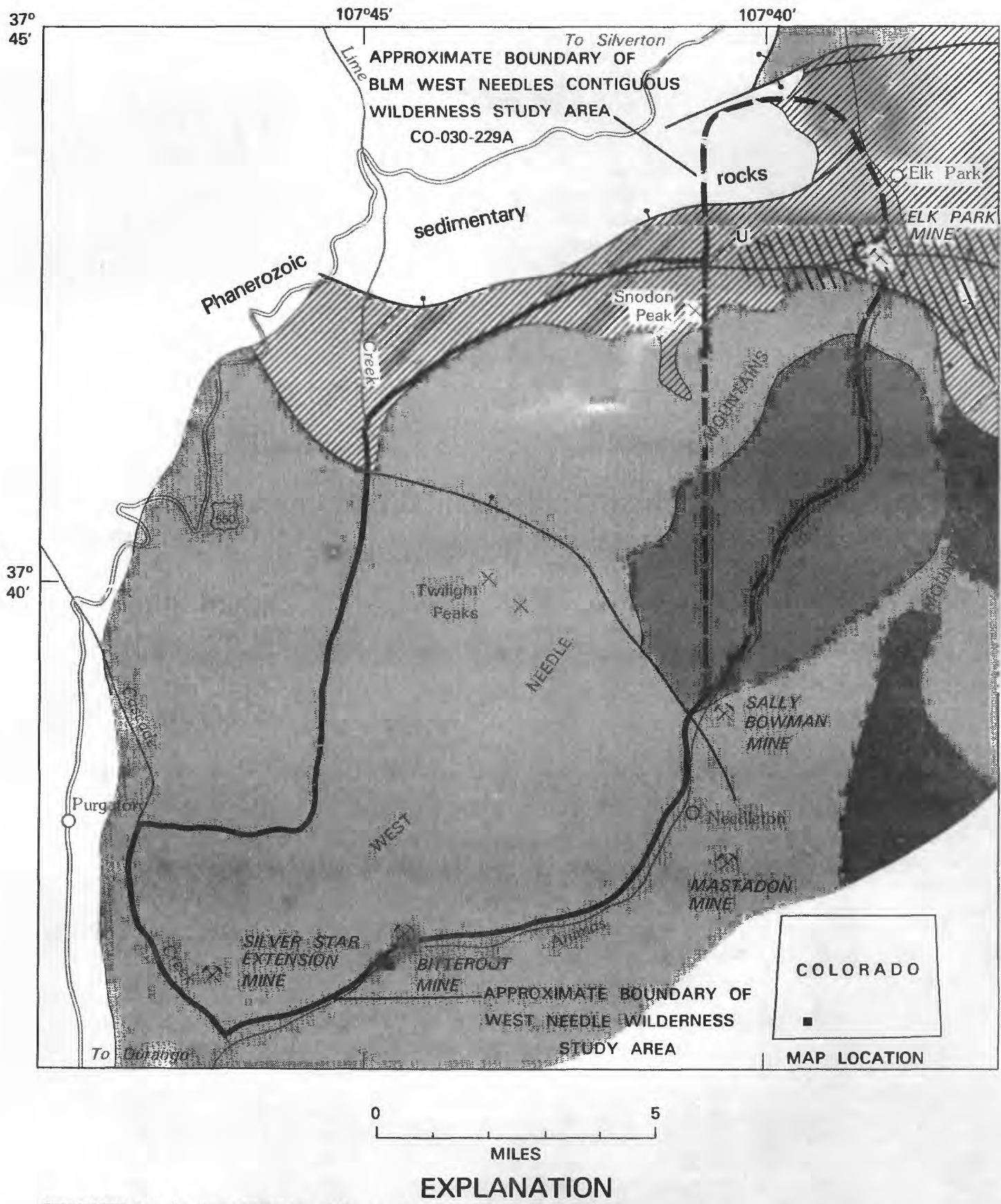

NIIIV Geologic terrane with moderate mineral-resource potential for uranium

u Uranium

父 Mine

Uncompahgre Formation (Proterozoic)

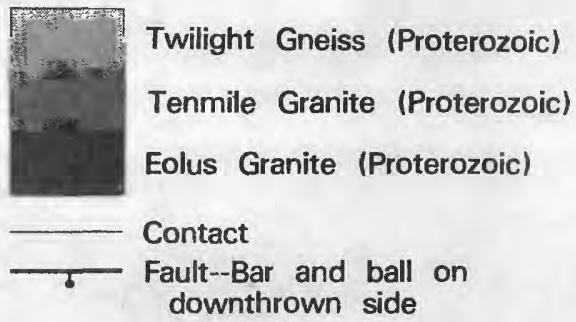

Figure 2.--Simplified geology and mineral resource potential for the West Needle Wilderness Study Area, Colorado. 
Molybdenum, tungsten, and cobalt can be found in trace amounts in most panned concentrates from streams within the region. The widespread distribution of these metals is suggestive of a regional background rather than the presence of a mineral deposit.

\section{GEOPHYSICS}

Detailed geophysical data are not available for the study area; however, the area is included as part of regional studies by Plouff and Pakiser (1972) and in a U.S. Geological Survey aeromagnetic map (U.S. Geological Survey, 1972).

The Proterozoic rocks in the West Needle Mountains generally have no strong gravity or magnetic expression. A gravity high centered in the Columbine Lake area to the southwest is probably due to the Electra Lake Gabbro (Proterozoic Y) (Plouff and Pakiser, 1972). This rock unit is shown as a magnetic low on the U.S. Geological Survey aeromagnetic map (U.S. Geological Survey, 1972). These data are a reflection of the slightly different physical properties between the gabbro and the rest of the Proterozoic rock terrane. Magnetic contours over the study area show a very uniform increase from south to north and west to east. The increase in the magnetic field across the area is due to the presence of Tertiary igneous rocks which crop out to the north and east of the study area.

\section{MINING DISTRICTS AND MINERAIIZED AREAS}

\section{Claims, mines, and prospects}

County records in Durango and Silverton, Colo., were examined for locations of mining claims. Location records for patented and unpatented mining claims on file with the U.S. Bureau of Land Management in Denver, Colo., were also examined.

Field studies included examining known mines, prospects, and mineralized areas inside and within $2 \mathrm{mi}$ of the study area. Attention was given to known types of mineral occurrences within the 2-mi outer periphery of the study area in order to determine if the mineralization in these areas extends inside the WSA. Accessible mine workings were mapped, and 161 samples were collected and analyzed. For a map of the claim locations, mines and prospects, and analytical results, refer to Scott (1983).

\section{Mining activity}

The West Needle Wilderness Study Area includes parts of two mining districts and is near a third (fig. 1). The southern part of the West Needle Wilderness Study Area (in La Plata County) includes the western part of the Needle Mountains mining district. The Cascade mining district is approximately 2 mi west of the western boundary of the West Needle Wilderness Study Area. The northern part of the West Needle Wilderness Study Area (in San Juan County) includes the southwest part of the Animas mining district.

Prospecting activity in the West Needle Wilderness Study Area was probably coincident with mining in the Needle Mountains mining district, as early as 1881 (Scott, 1983). Cross and others (1905, p. 12) reported that extensive prospecting had been carried on in the district prior to the time of their study. Mining activity continued intermittently through 1917 and was renewed briefly in 1934 after the price of gold increased to $\$ 35$ per oz (Steven and others, 1969 , p. 92). At the time of this study no mining activity or prospecting was observed in the Needle Mountains mining district in or near the southern part of the West Needle Wilderness Study Area.

In 1956, uranium was discovered at the Elk Park mine, on the eastern boundary of the WSA (fig. 2). Work during 1958-60 consisted of driving a 400-ft adit, and from 1960 to 1978 only assessment work was done (Scott, 1983). Exxon Minerals Company initiated a drilling program in $1980-81$ in the Elk Park mine area (Centennial deposit). No mining activity was observed at the mite in June 1982.

In the study area, as of September 1982, no patented claims were on record with the U.S. Bureau of Land Management; however, 210 umpatented claims are on record within the WSA. Most of the claims in the study area were staked by Exxon Minerals Company during their exploration for uranium in 198081 at the Elk Park mine. Since September 1982 these claims have been dropped by Exxon.

During the time of this study, assessment work and prospecting were being done only at the Hidden Hole prospect (Scott, 1983), located inside the western boundary of the WSA (fig. 3 ).

\section{Mineralized areas}

Several small mines and prospects (see fig. 3 for locations) were examined both within and near the West Needle Wilderness Study Area.

The Mastodon mine, on patented claims $1 \mathrm{mi}$ east of the WSA, consists of workings on quartz-pyrite fissure veins within fault zones in the Twilight Gneiss. These veins appear to pinch out in the gneiss and do not extend into the study area. Silver was probably produced from this mine (Scott, 1983).

A similar mineral occurrence is located within the WSA at the Bitterroot mine. These workings, on unpatented claims, are on quartz-pyrite-calcite veins within fault zones in the Twilight Gneiss. It is uncertain if this mine ever produced, but it reportedly contained tungsten, native gold, and auriferous pyrite (Silver, 1957).

The Silver Star Extension mine, located in the southwestern part of the WSA, is also in a fault zone in the Twilight Gneiss. Talus covers the portal of the adit, and the vein was not visible on the surface. No mineral resource potential could be determined from information available, and the vein could not be traced on the surface.

An adit at Purgatory Flats, west of the study area, was driven on a quartz-pyrite vein within a fault zone in the Twilight Gneiss. This fault zone does not extend into the WSA. Minor amounts of gold and silver were detected in samples of the vein.

The Hidden Hole prospect, located just inside the northwestern boundary of the WSA, exposes two northeast-trending fault zones in the Uncompahgre Formation. Analytical data for samples from the prospect show no base- or precious-metal values sufficient to identify a mineral resource (Scott, 1983).

The area north of Columbine Lake, $1 \mathrm{mi}$ southwest of the study area, contains a number of prospects and shafts on mineralized fault zones in 


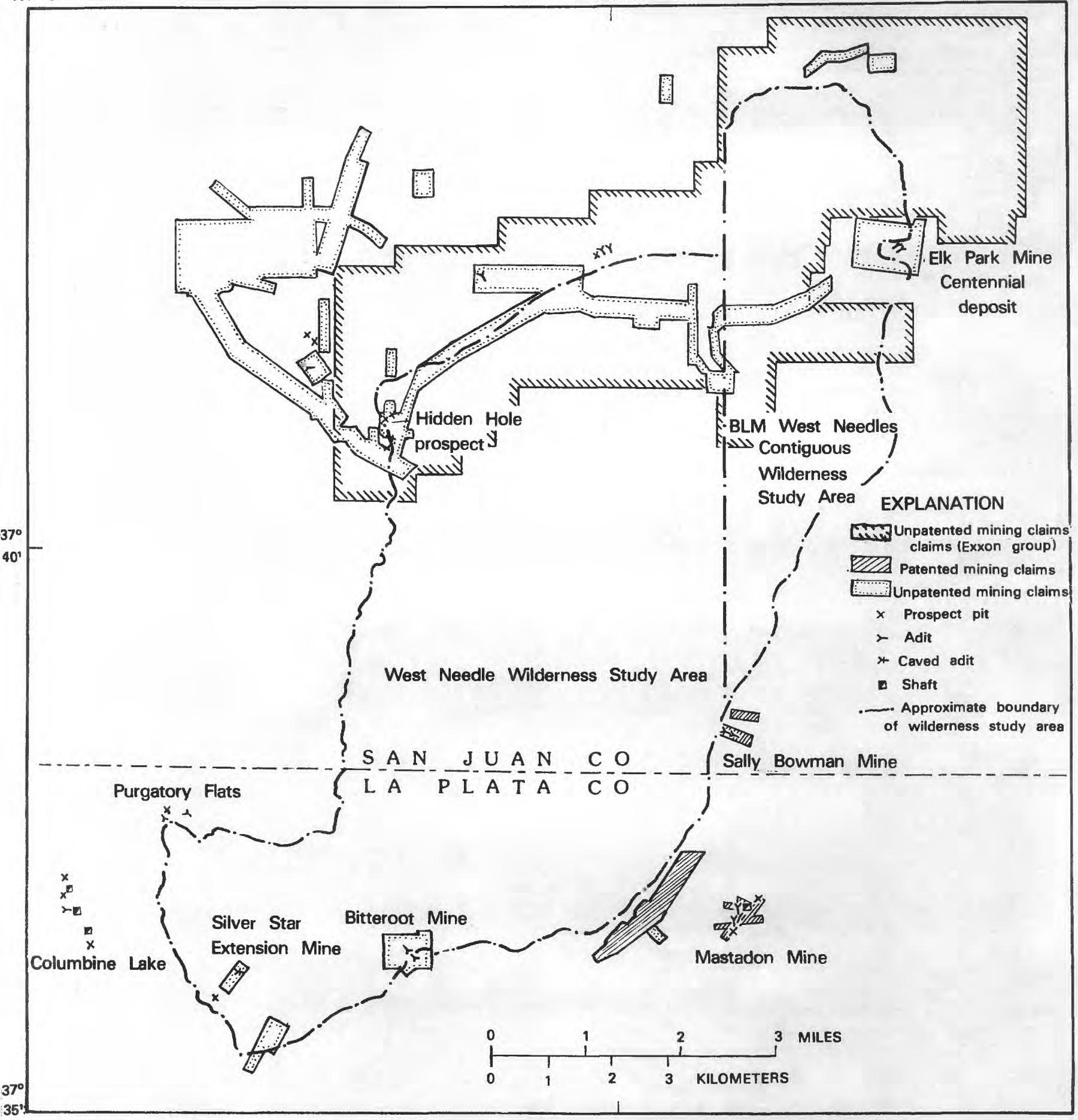

Figure 3.--Mine and prospect map of the West Needle Wilderness Study Area (which includes the BLM West Needles Contiguous Wilderness Study Area), San Juan and La Plata Counties, Colorado. 
Paleozoic limestones. Silver, from 0.2 to $28 \mathrm{oz}$ per ton of ore, and base metals were detected in these veins; however, the host limestones do not extend into the WSA.

Paleozoic limestones north of the study area contain barite, calcite, copper, lead, and silver in fault-controlled veinlets. These veinlets pinch out rapidly and cannot be traced into the WSA.

The Sally Bowman mine, located on the fringe of the east-central boundary of the WSA, is on a small fault-controlled fissure vein in the Twilight Gneiss. Traces of gold and silver were found in dump samples. This vein cannot be traced into the WSA.

In 1956, uranium was discovered near the west bank of the Animas River in Elk Park near the WSA boundary. In 1957, a Defense Mineral Exploration Assistance contract was granted to explore the deposit. Sporadic production since then has amounted to some 300 tons of ore that averaged approximately 0.2 percent $\mathrm{U}_{3} \mathrm{O}_{8}$ (Scott, 1983). Exxon Minerals Company's extensive drilling program during 1980 and 1981 located a potentially large mineralized body. This zone of mineralized rock lies along the study area boundary, as indicated from surface and subsurface exploration. The known surface extent of this deposit, referred to as the Centennial deposit, is at least twice the size of the surface expression for the 40-millionpound Schwartzwalder uranium mine, Jefferson County, Colo. (Bailey, 1982).

The uranium mineralization is of the fissure-vein type and occurs in fractures in the Uncompahgre Formation. In the vicinity of Elk Park the formation is intensely folded and fractured along east-west trends and the mineralized zone is confined between two major faults (Bailey, 1982). The fracture zone between the faults has been intruded by a network of rhyolite porphyry and diabase dikes (probably Proterozoic $Y$ in age) (Bailey, 1982). Bailey suggests that the rhyolite porphyry dikes correlate with the Trimble Granite also of Proterozoic Y age. Moreover, the Trimble Granite, which intrudes the Eolus Granite east of Elk Park, is a uraniferous pluton that commonly contains more than $10 \mathrm{ppm}$ uranium. The Trimble Granite also has a small identified fissure-vein uranium deposit near Florida Peak, southeast of the study area.

Uranium in the Centennial deposit occurs entirely in veins that range in size from tiny fractures in the quartzites to major fault breccias. The uranium is associated with pyrite and hematite in simple veins or in complex veins containing essentially amorphous sulfides and arsenates (Bailey, 1982). Zoning is suggested, as the uranium grades tend to increase with depth and the base- and precious-metal grades decrease. Significant concentrations of copper, molybdenum, lead, zinc, silver, nickel, and cobalt occur either with or without uranium in the deposit (Bailey, 1982). Forty-four minerals, including sulfides, arsenates, phosphates, carbonates, oxides, sulfates, silicates, and sulfosalts have been identified from the Centennial deposit (Bailey, 1982). Many of these minerals are previously unidentified in Colorado.

The thick intercalated black slates and phyllites of the Uncompahgre Formation commonly are radioactive. Scintillometer readings taken during this study over the slates and phyllites exposed on the Lime Creek road were commonly above and often several times greater than background level. Burns and others
(1980) reported black slates from other parts of the formation containing as much as $300 \mathrm{ppm}$ uranium; however, samples from the Lime Creek area ranged from only 4 to $20 \mathrm{ppm}$ uranium.

The origin of uranium in the Centennial deposit is problematical. Two possible sources include the Proterozoic $Y$ uraniferous plutons of the Needle Mountains, as suggested by Bailey (1982), or the pelitic rocks of the Uncompahgre Formation, which commonly contain slightly anomalous amounts of uranium. During metamorphism, trace amounts of uranium from these thick sections of shale may have been concentrated in structurally prepared rocks by a process such as lateral secretion. If the black shales did indeed provide the uranium for the Centennial deposit, then it is conceivable other deposits might exist, given the same favorable conditions, elsewhere in the Uncompahgre Formation.

\section{ASSESSMENT OF MINERAL RESOURCE POTENTIAL}

Mineralization in this region is predominantly related directly to igneous activity during Tertiary time. Most significant evidence of this igneous activity is the Silverton cauldron complex located $8 \mathrm{mi}$ north of the study area, which contains base and precious metals in zones of alteration, in subsidence structures, and in fractures in the underlying older rocks. The West Needle Wilderness Study Area does not contain Tertiary igneous rocks, and it probably was not affected by the nearby volcanic activity.

Although the study area is contiguous to several mining districts, only a small part of the area has a moderate mineral resource potential for uranium. This area is west of the Elk Park mine, in the northeastern part of the area within the Bureau of Land Management West Needles Contiguous Wilderness Study Area (CO-030-229A). Faulted fold structures that localized uranium in the mine extend westward into the study area.

Several small mines and prospects in and near the West Needle Wilderness Study Area were developed along quartz fissure veins in the Twilight Gneiss and in younger Paleozoic limestones. These veins contain traces of base and precious metals, but there are no indications of a potential for mineral resources.

\section{Uranium mineralization}

The area west of the Elk Park mine within the Bureau of Land Management wilderness study area is identified as having a moderate resource potential for uranium. Exxon Minerals Company's drilling program during 1980 and 1981 resulted in the delineation of a large uranium ore body, known as the Centennial deposit, located on 80 acres that were excluded from the West Needle Wilderness Study Area. This deposit also contains significant concentrations of copper, molybdenum, lead, zinc, silver, nickel, and cobalt (Bailey, 1982).

Although the Centennial deposit is located outside the West Needle Wilderness Study Area boundary, the east-west structures that localized the mineralized body can be traced well inside the study area. No surface indications of mineralization were found inside the study area; however, it is reasonable to assume that mineralization may occur at depth 
along the known faulted fold structures. These structures, within the study area, will probably remain untested until the eventual development of the Centennial deposit. Serious exploitation of the Centennial deposit will be difficult because of the very rough terrain and limited access. The only access to the mine is that provided by the Durango-Silverton Narrow Gauge Railroad which operates only during the summer months.

Metasedimentary rocks of the Uncompahgre Formation (Proterozoic age) are widespread in the northern part of the West Needle Wilderness Study Area. They consist of nearly $8,000 \mathrm{ft}$ of interlayered quartzite, slates, and a thin discontinuous section of basal conglomerate along an east-west-trending fold belt. The basal conglomerate was the subject of intensive studies by Burns and others (1980) in an evaluation for fossil-placer uranium for the U.S. Department of Energy. Their conclusions, based on analytical data, studies of depositional environments, and age restraints for that type of mineralization, indicated that the conglomerate was an unlikely host for placer uranium.

\section{Base and precious metals}

Several small mines and prospects in and near the West Needle Wilderness Study Area, northwest part of the Needle Mountain district, were developed along quartz fissure veins containing minor amounts of base and precious metals. These veins occupy minor fault zones in the Twilight Gneiss. The Silver Star Extension mine and the Bitterroot mine are located on unpatented claims on Forest Service land within the southern part of the West Needle Wilderness Study Area. These veins occupy minor fault zones in the Twilight Gneiss. No records of production were found, and analytical data from samples collected from all of these old workings do not indicate the presence of mineral resources. Similar fractures in the younger overlying limestones to the north and west of the study area also contain traces of mineralization. Small isolated patches of limestone crop out within the study area; however, no indication of mineralization was found.

On the basis of analyzed samples, the limited nature of the controlling structures, and past records of production, the area of fissure veins in either the Twilight Gneiss or the overlying younger limestones in the West Needle Mountain Wilderness Study Area have low mineral resource potential.

Traces of gold can be found in Lime Creek sediments but not in amounts that would indicate a resource.

Barker (1969a) studied the Precambrian Uncompahgre Formation for possible fossil placer deposits of gold. Barker concluded that the Uncompahgre Formation is not a potential source for gold; most samples contain less than $0.1 \mathrm{ppm}$ gold. Barker also analyzed carbonaceous slates of the formation for 29 other metals; however, all of the slates analyzed have a predominantly low metal content.

\section{Oil and gas}

As of September 1982, there were no oil and gas leases or applications inside or within $2 \mathrm{mi}$ of the West
Needle Wilderness Study Area. The geologic terrain precludes the occurrence of oil and gas resources.

\section{REFERENCES CITED}

Bailey, M. H., 1982, Evaluation of the Centennial uranium deposit-A report on the geology and exploration results: Exxon Minerals Company Administrative Report, $40 \mathrm{p}$.

Barker, Fred, 1969a, Gold investigations in Precambrian clastic and pelitic rocks, southwestern Colorado and northern New Mexico: U.S. Geological Survey Bulletin 1272-F, $22 \mathrm{p}$.

1969b 1970. Precambrian geology of the Needle Mountains, southwestern Colorado: U.S. Geological Survey Professional Paper 644-A, 35 p.

Birminghán, S. D., and Van Loenen, R. E., 1983, Geochemical data from the West Needle and West Needle Contiguous Wilderness Study Areas, San Juan and La Plata Counties, Colorado: U.S. Geological Survey Open-File Report 83-814.

Burns, L. K., Ethridge, F. G., Tyles, N., Gross, A. S., and Campo, A. M., 1980, Geology and uranium evaluation of the Precambrian quartz-pebble conglomerates of the Needle Mountains, southwest Colorado: National Uranium Resource Evaluation, U.S. Department of Energy GJBX$118(80)$.

Cross, Whitman, and Hole, A. D., 1910, Engineer Mountain Quadrangle: U.S. Geological Survey Geologic Atlas of the United States Folio 171, 14 p.

Cross, Whitman, Howe, Ernest, Irving, J. D., and Emmons, W. H., 1905, Needle Mountains Quadrangle: U.S. Geological Survey Geologic Atlas of the United States Folio 131, 14 p.

Plouff, Donald, and Pakiser, L. C., 1972, Gravity study of the San Juan Mountains, Colorado, in Geological Survey Research 1972: U.S. Geological Survey Professional Paper 800-B, p. B183-B190.

Scott, D. C., 1983, Mine and prospect map of the West Needle Wilderness Study Area and the Bureau of Land Management West Needle Contiguous Wilderness Study Area, La Plata and San Juan Counties, Colorado: U.S. Geological Survey Miscellaneous Field Studies Map MF-1632-C, scale $1: 50,000$.

Silver, Coswell, 1957, Guidebook of southwestern San Juan Mountains, Colorado: New Mexico Geological Society 8 th Field Conference, p. 85.

Steven, T. A., Schmitt, L. J., Jr., Sheridan, M. J., and Williams, F. E., 1969, Mineral resources of the San Juan Primitive Area, Colorado: U.S. Geological Survey Bulletin 1261-F, 187 p.

U.S. Geological Survey, 1972, Aeromagnetic map of the Ridgway-Pagosa Spring area, southwestern Colorado: U.S. Geological Survey Geophysical Investigations Map GP-840, scale 1:250,000.

Van Loenen, R. E., 1983, Geologic and geochemical map of West Needle Wilderness Study Area, La Plata and San Juan Counties, Colorado: U.S. Geological Survey Miscellaneous Field Studies Map, MF-1632-B, scale 1:50,000. 